\title{
Protective effect of edaravone on rat testis after valproic acid treatment
}

\author{
Cagri CELIK ${ }^{1}$ (D), Bertan Boran BAYRAK ${ }^{1 *}$ (D) , Neziha HACIHASANOGLU CAKMAK ${ }^{2}$ (D) , \\ Refiye YANARDAG ${ }^{1}$ (D)
}

1 Department of Chemistry, Faculty of Engineering, Istanbul University-Cerrahpaşa, Avcilar 34320 Istanbul, Turkey.

2 Pharmacy Services, Vocational School of Health Services, Istanbul Medipol University, Beykoz 34810 Istanbul, Turkey.

* Corresponding Author. E-mail: bertanb@iuc.edu.tr (B.B.B.); Tel. +90-212-473 70 70, Fax. +90-212-473 7180.

Received: 27 July 2021 / Revised: 25 August 2021 / Accepted: 04 September 2021

\begin{abstract}
Valproic acid (n-dipropyl-acetic acid, VPA) is a medication used as anticonvulsant in the treatment of bipolar disorder, and for migraine prophylaxis. Long-term use of VPA is known to trigger reproductive impairment, which is mediated by elevation of testicular oxidative stress. Edaravone is used in the treatment of cerebrovascular diseases. It can diffuse into many disease-affected organs, thus shows protective effects in numerous tissues including the heart, lung, and testis. The main goal of the present study was to determine the possible protective role of edaravone against VPA-induced oxidative testicular injury. Male Sprague Dawley rats were assigned into four groups. Control rats; rats given only edaravone (30 mg/ kg/day); rats given only VPA (500 mg/kg/day); rats given VPA+edaravone for seven days. Edaravone and VPA were applied intraperitoneally. After eight days, testicular tissues were taken from rats. There was a statistically significant increase in the levels of reduced glutathione, lipid peroxidation, reactive oxygen species, total oxidant status, oxidative stress index, and DNA contents as well as catalase, superoxide dismutase, glutathione-related enzymes, gamma-glutamyl transferase, acid and alkaline phosphatases, lactate dehydrogenase, myeloperoxidase and sorbitol dehydrogenase activities in VPA group. More so, advanced oxidized protein products, protein carbonyl, and nitric oxide levels were also significantly increased in VPA group. Activities of glucose-6phosphate dehydrogenase and sodium/potassium ATPase and total antioxidant status levels remarkably decreased in VPA given group. Treatment with edaravone to VPA group significantly reverted these alterations. These findings demonstrate that administration of edaravone has a beneficial effect against testicular injury in VPA-induced oxidative stress.
\end{abstract}

KEYWORDS: Edaravone; testis injury; valproic acid; oxidative stress parameters; antioxidant enzymes.

\section{INTRODUCTION}

Valproic acid (n-dipropyl-acetic acid, VPA), a low molecular weight carboxylic acid, is a broadspectrum medication generally used in both children and adults for treatment of epilepsy, mood stabilization in bipolar disorder, as anticonvulsant against seizures, and management of various other conditions such as migraine and neuropathic pain [1]. The antiepileptic properties of VPA have been associated with its ability to inhibit the degradation of gamma-aminobutyric acid (GABA). Also, it is used as an antineoplastic agent via its histone deacetylase inhibition [2]. Long-term use of VPA has been reported to have some toxic and/or side effects on several organs such as the liver [3], kidney [4], and testis [5]. In recent years, studies have shown that VPA has adverse effects on male reproductive system (sperm motility) in both male epileptic patients [6] and experimental animal model [7]. These adverse effects have been reported that the use of VPA together with chronic stress or diabetes give rise to altering the expression of specific proteins in seminal tissue and fluids for example androgen receptors and tyrosine phosphorylated proteins [8,9]. Furthermore, it is known to trigger reproductive impairment, which is mediated by elevation of testicular oxidative stress [10]. However, VPA is reported to reduce the secretion of sex hormones and their metabolites such as luteinizing hormone (LH), follicle-stimulating hormone (FSH), testosterone, dehydroepiandrosterone sulfate (DHEAS) [11].

The continuous formation and elimination of free radicals including reactive oxygen species (ROS) are strictly controlled by a system called as redox balance. A disturbance of this redox balance favors ROS, thereby

How to cite this article: Celik C, Bayrak BB , Hacıhasanoğlu Cakmak N, Yanardag R. Protective effect of edaravone on rat testis after valproic acid treatment. J Res Pharm. 2022; 26(1): 52-62. 
causing oxidative stress $[12,13]$. These precipitate the development of a wide variety of diseases, including cancer, diabetes, and testicular damage [14]. In the biological system, several intra- and extracellular molecules, and enzymes commonly referred to as antioxidants act against deleterious effects of ROS [15].

Edaravone (3-methyl-1-phenyl-2-pyrazoline-5-one), a neuroprotective drug, was first developed in Japan. It has been shown to have novel and potent scavenging effects against ROS such as hydroxyl and peroxyl radicals [16]. Due to its amphiphilic property, it dissolves easily in both aqueous and lipid phases. Therefore, by giving an electron, edaravone neutralizes the harmful effects of peroxyl radicals in both hydrophilic and hydrophobic phases. It has been reported that edaravone may have important effects on oxidative stress-induced testicular damage [17].

The main objective of the current study was to assess the protective ability of edaravone against VPAinduced testicular damage.

\section{RESULTS}

Reduced glutathione (GSH) and lipid peroxidation (LPO) levels are shown in Figure 1. The levels of GSH in VPA group were obviously elevated than the control group $(\mathrm{P}<0.0001)$. LPO levels notably declined in edaravone group $(\mathrm{P}<0.0001)$, whereas the levels of LPO notably increased in VPA group $(\mathrm{P}<0.001)$ compared to control rats. There was a significant recovery of both GSH $(\mathrm{P}<0.001)$ and LPO levels $(\mathrm{P}<0.0001)$ when edaravone was administered to VPA group (Figure 1).
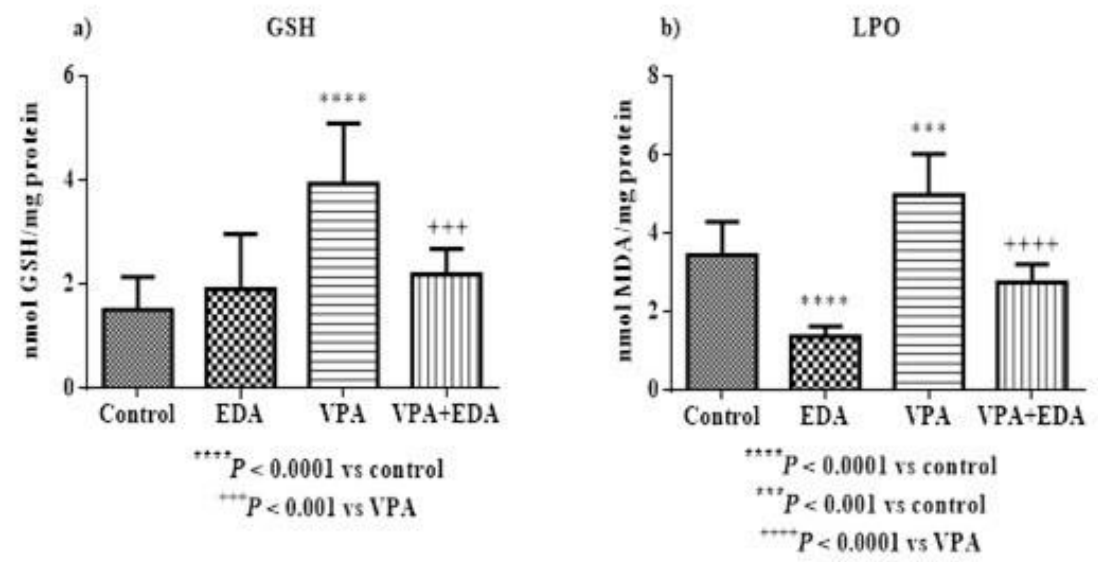

Figure 1. Effect of edaravone on testis tissue reduced glutathione and lipid peroxidation levels of control and experimental groups of rats. a) GSH, b) LPO. Data were presented as mean \pm S.D. Statistical significance between the groups was employed by one-way ANOVA using a Tukey's post hoc multiple comparison test. Abbreviations: S.D., standard deviation; ANOVA, analysis of variance; EDA, edaravone.

ROS, total oxidant status (TOS), total antioxidant status (TAS), and oxidative stress index (OSI) levels are depicted in Figure 2. ROS, TOS, and OSI levels were remarkably elevated $(\mathrm{P}<0.0001$ and $\mathrm{P}<0.001)$, while TAS levels were notably abated $(\mathrm{P}<0.0001)$ in VPA group when compared to control group. On the contrary, application of edaravone to VPA group resulted in a remarkable decline in ROS $(\mathrm{P}<0.0001)$, TOS $(\mathrm{P}<0.01)$, and OSI $(\mathrm{P}<0.0001)$ levels, and remarkably increased TAS levels $(\mathrm{P}<0.0001)$ (Figure 2).

Activities of catalase (CAT), superoxide dismutase (SOD), glutathione peroxidase (GPx), glutathione reductase (GR), and glutathione-S-transferase (GST) of experimental groups are presented in Table 1. A remarkable increase in both CAT and SOD activities were detected VPA groups $(\mathrm{P}<0.01$ and $\mathrm{P}<0.0001)$ when compared with control group (Table 1). Moreover, a considerable elevation of GPx, GR, and GST activities in VPA groups compared with control rats $(\mathrm{P}<0.0001)$ was observed (Table 1$)$. However, edaravoneadministered VPA group had remarkably decreased activities of testicular antioxidant enzymes $(\mathrm{P}<0.001$ and $\mathrm{P}<0.0001)$ (Table 1).

Acid phosphatase (ACP), alkaline phosphatase (ALP), and lactate dehydrogenase (LDH) activities of experimental groups are shown in Table 2. There was a remarkable rising in the activities of ACP, ALP, and LDH in VPA given rats as compared to control rats $(\mathrm{P}<0.0001)$. The administration of edaravone to VPA group brought about a significant decline in the ACP, ALP, and LDH activities, respectively $(\mathrm{P}<0.0001$ and $\mathrm{P}$ $<0.05)$ (Table 2). 
Table 1. Testis tissue CAT, SOD, GPx, GR, and GST activities control and experimental groups of rats.

\begin{tabular}{lccccc}
\hline Groups & $\begin{array}{c}\text { CAT } \\
\text { (U/mg } \\
\text { protein)* }\end{array}$ & $\begin{array}{c}\text { SOD } \\
\text { (U/mg } \\
\text { protein) }\end{array}$ & $\begin{array}{c}\text { GPx } \\
\text { (U/g protein) }^{*}\end{array}$ & $\begin{array}{c}\text { GR } \\
\text { (U/g } \\
\text { protein) }^{*}\end{array}$ & $\begin{array}{c}\text { GST } \\
\text { (U/mg protein)* }\end{array}$ \\
\hline Control & $2.53 \pm 1.22$ & $0.28 \pm 0.05$ & $299.00 \pm 25.80$ & $11.94 \pm 1.90$ & $0.43 \pm 0.05$ \\
Control + EDA & $2.48 \pm 0.91$ & $0.38 \pm 0.03$ & $274.90 \pm 60.40$ & $12.96 \pm 1.59$ & $0.46 \pm 0.06$ \\
VPA & $4.51 \pm 0.45^{\mathrm{a}}$ & $0.71 \pm 0.07^{\mathrm{c}}$ & $491.40 \pm 36.79 \mathrm{c}$ & $16.85 \pm 1.95^{\mathrm{c}}$ & $0.61 \pm 0.05^{\mathrm{c}}$ \\
VPA + EDA & $2.06 \pm 0.56^{\mathrm{b}}$ & $0.26 \pm 0.04^{\mathrm{d}}$ & $335.10 \pm 34.70^{\mathrm{d}}$ & $11.80 \pm 1.19 \mathrm{~d}$ & $0.51 \pm 0.03^{\mathrm{b}}$
\end{tabular}

*Data were presented as mean \pm S.D. aP $<0.01$ vs control. $\mathrm{bP}<0.001$ vs VPA. $\mathrm{cP}<0.0001$ vs control. $\mathrm{dP}<0.0001$ vs VPA. Statistical significance between the groups was employed by one-way ANOVA using a Tukey's post hoc multiple comparison test. Abbreviations: S.D., standard deviation; ANOVA, analysis of variance; EDA, edaravone.
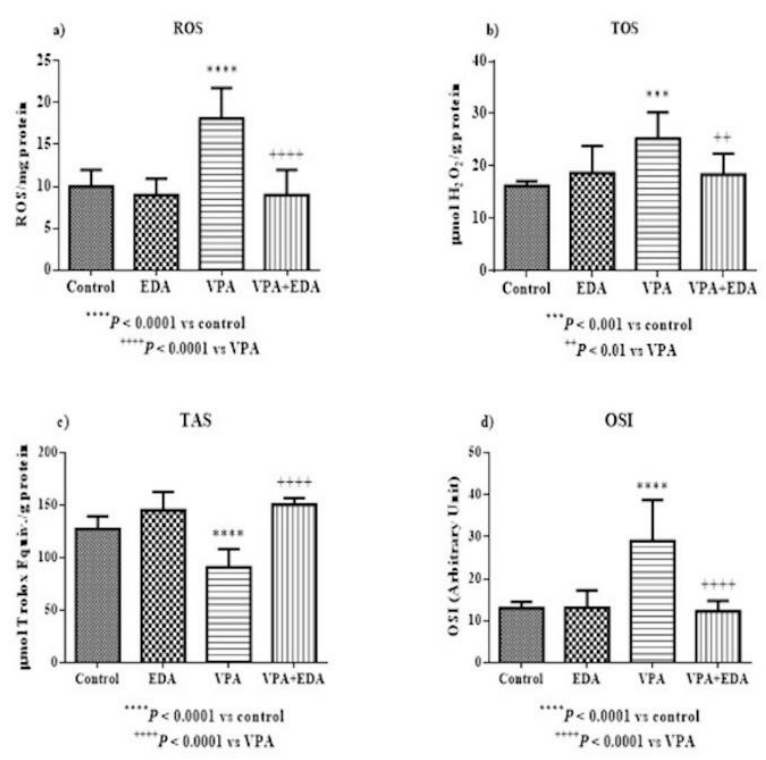

Figure 2. Effect of edaravone on testis tissue reduced reactive oxygen species, total oxidant status, total antioxidant status, and oxidative stress index levels of control and experimental groups of rats. a) ROS, b) TOS, c) TAS, d) OSI. Data were presented as mean \pm S.D. Statistical significance between the groups was employed by one-way ANOVA using a Tukey's post hoc multiple comparison test. Abbreviations: S.D., standard deviation; ANOVA, analysis of variance; EDA, edaravone.

The gamma-glutamyl transferase (GGT), sodium/potassium ATPase $\left(\mathrm{Na}^{+} / \mathrm{K}^{+}\right.$-ATPase), myeloperoxidase (MPO), glucose-6-phosphate dehydrogenase (G6PD), and sorbitol dehydrogenase (SDH) activities of experimental groups are depicted in Table 3. As seen in Table 3, an obvious increase in GGT, MPO, and SDH activities was detected in VPA given rats than that of control rats $(\mathrm{P}<0.0001$ and $\mathrm{P}<0.001)$. On the other hand, G6PD and $\mathrm{Na}^{+} / \mathrm{K}^{+}$-ATPase activities remarkably declined in VPA groups as compared to control group $(\mathrm{P}<0.001$ and $\mathrm{P}<0.01)$. The application of edaravone to VPA group brought about a notable decline in the activities of GGT, MPO, and SDH $(\mathrm{P}<0.001$ and $\mathrm{P}<0.0001)$, and a notable elevation in the activities of G6PD $(\mathrm{P}<0.0001)$, and $\mathrm{Na}^{+} / \mathrm{K}^{+}$-ATPase $(\mathrm{P}<0.05)$ (Table 3).

Testicular tissue levels of advanced oxidized protein products (AOPP), protein carbonyl contents (PC), and nitric oxide (NO) levels and deoxyribonucleic acid (DNA) contents of experimental groups are given in Figure 3 . The content of DNA in the edaravone group was remarkably higher than that of control group $(\mathrm{P}<$ 0.001). Moreover, the levels of AOPP, PC, NO, and DNA contents in the VPA group were obviously elevated when compared to control group $(\mathrm{P}<0.0001$ and $\mathrm{P}<0.001)$. Treatment of the VPA group with edaravone resulted in a significant decrease in all these parameters in testis tissue $(\mathrm{P}<0.0001)$ (Figure 3$)$. 
Table 2. Testis tissue ACP, ALP, and LDH activities of control and experimental groups of rats.

\begin{tabular}{lccc}
\hline Groups & $\begin{array}{c}\text { ACP } \\
\text { (U/g protein) }^{*}\end{array}$ & $\begin{array}{c}\text { ALP } \\
\text { (U/g protein)* }^{*}\end{array}$ & $\begin{array}{c}\text { LDH } \\
\text { (U/g } \\
\text { protein)* }\end{array}$ \\
\hline Control & $28.66 \pm 1.63$ & $27.10 \pm 2.36$ & $16.99 \pm 4.05$ \\
Control + EDA & $26.14 \pm 3.25$ & $33.41 \pm 5.08$ & $20.33 \pm 5.71$ \\
VPA & $35.62 \pm 3.50^{\mathrm{a}}$ & $46.04 \pm 7.81^{\mathrm{a}}$ & $36.88 \pm 4.48^{\mathrm{a}}$ \\
VPA + EDA & $27.66 \pm 2.64^{\mathrm{b}}$ & $37.97 \pm 5.68^{\mathrm{c}}$ & $15.92 \pm 2.37 \mathrm{~b}$
\end{tabular}

${ }^{*}$ Data were presented as mean \pm S.D. ${ }^{\text {a }}<<0.0001$ vs control. ${ }^{\mathrm{b}} \mathrm{P}<0.0001$ vs VPA. $\mathrm{c} P<0.05$ vs VPA. Statistical significance between the groups was employed by one-way ANOVA using a Tukey's post hoc multiple comparison test. Abbreviations: S.D., standard deviation; ANOVA, analysis of variance; EDA, edaravone.

Table 3. Testis tissue GGT, G6PD, MPO, $\mathrm{Na}^{+} / \mathrm{K}^{+}$-ATPase, and SDH activities of control and experimental groups of rats.

\begin{tabular}{|c|c|c|c|c|c|}
\hline Groups & $\begin{array}{c}\text { GGT } \\
(\mathrm{U} / \mathrm{g} \\
\text { protein }^{*}\end{array}$ & $\begin{array}{c}\text { G6PD } \\
\text { (U/g } \\
\text { protein)* }\end{array}$ & $\begin{array}{c}\text { MPO } \\
\text { (mU/g } \\
\text { tissue)* }\end{array}$ & $\begin{array}{c}\mathrm{Na}^{+} / \mathrm{K}^{+}-\mathrm{ATPase} \\
\left(\mathrm{nmol} \mathrm{P}_{\mathrm{i}} / \mathrm{mg}\right. \\
\text { protein/h) }^{*}\end{array}$ & $\begin{array}{c}\text { SDH } \\
(\mathrm{U} / \mathrm{g} \\
\text { protein)* }\end{array}$ \\
\hline Control & $35.58 \pm 8.83$ & $10.62 \pm 0.87$ & $4.61 \pm 0.55$ & $14.67 \pm 3.46$ & $15.21 \pm 3.01$ \\
\hline Control + EDA & $43.98 \pm 7.48$ & $8.40 \pm 0.70$ & $3.84 \pm 0.92$ & $11.66 \pm 0.68$ & $18.27 \pm 5.84$ \\
\hline VPA & $60.36 \pm 9.59 a$ & $6.22 \pm 1.08^{c}$ & $7.88 \pm 0.70^{a}$ & $7.81 \pm 1.41^{\mathrm{e}}$ & $26.71 \pm 7.01 \mathrm{c}$ \\
\hline $\mathrm{VPA}+\mathrm{EDA}$ & $44.77 \pm 6.66^{b}$ & $12.39 \pm 0.23^{\mathrm{d}}$ & $3.77 \pm 0.73^{d}$ & $15.57 \pm 3.08^{\mathrm{f}}$ & $15.13 \pm 4.48^{b}$ \\
\hline
\end{tabular}

${ }^{*}$ Data were presented as mean \pm SD. $\mathrm{aP}<0.0001$ vs control. $\mathrm{bP}<0.001$ vs VPA. $\mathrm{cP}<0.001$ vs control. $\mathrm{dP}<0.0001$ vs VPA. eP $<0.01$ vs control. $\mathrm{fP}<0.05$ vs VPA. Statistical significance between the groups was employed by one-way ANOVA using a Tukey's post hoc multiple comparison test. Abbreviations: S.D., standard deviation; ANOVA, analysis of variance; EDA, edaravone.

\section{DISCUSSION}

Although VPA is prescribed in the treatment of epilepsy and bipolar disorders [18], its long-term use has adverse/side effects on various tissues such as liver [19], kidney [4], and testis [5]. Increasing evidence obviously shows that administration of VPA triggers oxidative stress as a result of overproduction of ROS [20]. In the present study, LPO levels in edaravone group there was statistically lower than that of the control group. The reason for diminishing LPO levels in edaravone group may be due to the antioxidant effect of edaravone which is based on the quenching of hydroxyl radicals as well as inhibiting LPO [21]. On the contrary, both GSH and LPO levels were notably elevated in VPA given rats as compared to control group. The outcomes for GSH analysis are not consistent with findings of Vidya and Subramanian [22] who reported that GSH levels decreased in testis of sodium-valproate (SVP)-treated rat. In contrast, administration of 500 $\mathrm{mg} / \mathrm{kg}$ of SVP for seven days has been reported to result in elevation of GSH levels in the testicular tissues of rats [23]. The reason for the discrepancies in the GSH levels caused by VPA-mediated testicular damage may be due to the different test protocol conditions such as VPA or SVP treatment dose. On the other hand, our findings for LPO are in parallel with a recent paper [10]. Administration of edaravone to VPA given rats gave rise to the reversion of these alterations. Edaravone probably neutralizes ROS via its potent antioxidant role.

Highly reactive and harmful chemical species that occur as a result of insufficient reduction of oxygen in the organism are called ROS, which may bring about serious damage to the testicular tissue containing large amounts of polyunsaturated fatty acids [24]. Moreover, TOS is frequently used to determine the overall oxidant produced during oxidative stress, while TAS is used to evaluate the whole antioxidant status. On the other hand, the degree of oxidative stress, which can be considered as the main damage mechanism for organ injury, may also be determined by the evaluation of the levels of OSI [25-27]. In this study, ROS, TOS, and OSI levels in VPA given group were remarkably elevated, while TAS levels notably decreased compared to control rats. Current outcomes were in harmony with the findings of Savran et al. [28], who reported that an increase in TOS levels was concomitant to a decrease in TAS levels, thus increasing OSI levels in VPA-mediated in testicular toxicity. It was shown that TOS levels remarkably increased whereas TAS levels notably decreased in children with seizures taking sixty days on VPA monotherapy [29]. Present findings are line with our recent article [30]. In the present study, administration of edaravone to VPA given rats resulted in decreased ROS, 
TOS, and OSI levels and increased TAS levels. These findings may have noteworthy effects of edaravone against ROS induced testicular damage. Arslan et al. [31] revealed that treatment with edaravone led to a significant decline in TOS levels and an obvious elevation in TAS levels in experimental brain ischemia/reperfusion injury in rats. Present findings were consistent with the aforementioned study.
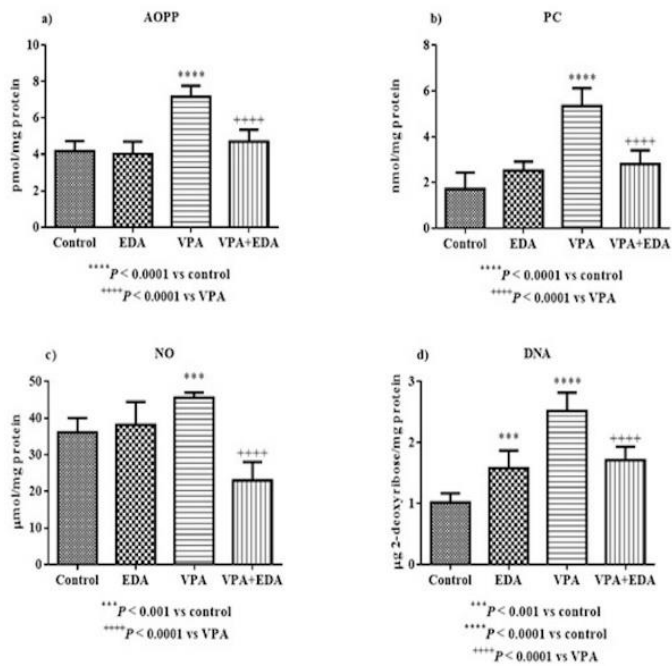

Figure 3. Effect of edaravone on testis tissue advanced oxidized protein products, protein carbonyl, nitrite oxide, and deoxyribonucleic acid levels of control and experimental groups of rats. a) AOPP, b) PC, c) NO, d) DNA. Data were presented as mean \pm SD. Statistical significance between the groups was employed by one-way ANOVA using a Tukey's post hoc multiple comparison test. Abbreviations: S.D., standard deviation; ANOVA, analysis of variance; EDA, edaravone.

The alteration of redox status in a cell, as well as microenvironment of the cell in favor of ROS-mediated oxidative stress, may also give rise to impairment of antioxidant balance. In the current study, it was observed that CAT, SOD, GPx, GR, and GST activities in VPA given group were significantly elevated when compared with control group. The possible explanation of these enhancements of enzyme activities may be linked to a chain reaction as follows: VPA treatment results in the generation of superoxide radicals, which in turn is converted to $\mathrm{H}_{2} \mathrm{O}_{2}$ by SOD. Because of the toxic nature of the generated $\mathrm{H}_{2} \mathrm{O}_{2}$, it has to be immediately disintegrated into water molecules by CAT or GPx. During GPx catalyzed decomposition of $\mathrm{H}_{2} \mathrm{O}_{2}$, the GSH is oxidized to GSSG, which is then reduced to GSH by GR. In addition, GSH (as a cofactor) is made use of by GST for the detoxification of organic hydroperoxides and other electrophiles derived as by-products from LPO [32]. The study of Ourique et al. [10] on VPA-induced toxicity against epididymides fraction of testes tissue of rats reveals that CAT, SOD, and GST activities were slightly elevated in VPA-treated group than in the control rats. It has been reported that CAT and GPx activities significantly increased, and SOD activity is slightly elevated in another study that examined Adriamycin induced toxicity on testis [33]. In our study, the application of edaravone to VPA group caused an obvious decrease in all these enzyme activities. These findings were in parallel with outcomes of Saini et al. [34]. On the contrary, a study on oxidative tissue damage showed that the activities of antioxidant enzymes decreased, but treatment with edaravone reversed these effects [35].

ACP is an enzyme widely distributed in lysosomal membranes of Sertoli cells of the testicular tissues. It provides a phosphate group to tissue, which is necessary during growth and development. It is known that ACP activities increase in many disease conditions (e.g., prostate cancer, bone-related disease, etc.) [36]. ALP is another enzyme that is associated with the activities of cell division, metabolism, and energy transfer. The measure of the alteration of the activities of these enzymes is a marker that indicates the degree of damage to the testicular tissue [37]. LDH is also closely associated with the maturation of spermatogenic cells and the energy metabolism of testes and spermatozoa [38]. In the current study, ACP, ALP, and LDH activities remarkably rose in VPA given rats when compared with control rats. Similar findings have been reported in two different studies conducted on the effects of flubendiamide and copper alone (or in combination) and cyclophosphamide on the testis, respectively [32,39]. An elevation of these enzyme activities may be due to disruption of membrane integrity, resulting from the deleterious effect of high ROS levels. In this study, edaravone treatment to rats of VPA group caused reverted effects on ACP, ALP, and LDH activities. These 
results may be associated with the ameliorative effect of edaravone that reduces the cellular oxidative stress, via interaction and regulation of testicular oxidative defense enzymes.

GGT is found on the outer surface of cellular membranes of many tissues, mainly the liver, kidney, pancreas, and testis [40]. GGT participates in preserving the physiological levels of cytosolic GSH and cellular defense against oxidative stress. Thus, elevated GGT activity is a biomarker of antioxidant inadequacy and elevated oxidative stress [41]. The enzymes participating in cysteine formation, which have a strong antioxidant effect play a pivotal role in GSH metabolism. Thus, GGT also helps support the intracellular antioxidant system. In the current study, GGT activities significantly elevated in the VPA given rats. GGT activity may be increased as a response to oxidative stress caused by VPA, facilitating further transport of GSH precursors into cells [42]. In a recently published study, it was stated that $500 \mathrm{mg} / \mathrm{kg}$ of VPA administration brought about an obvious elevation in GGT activities in the liver of rats [43]. Besides, the elevation of GSH levels in VPA group may be associated with an increase in GGT activities of the present study. G6PD, the ratelimiting and key-regulatory enzyme of the pentose phosphate pathway, is a primary source of NADPH that is required by many crucial cellular systems with the inclusion of the antioxidant pathways, nitric oxide synthase, NADPH oxidase, cytochrome P450 system [44]. The present study shows that VPA treatment to control rats caused an obvious decrease in G6PD activity. G6PD activity significantly increased as a result of the administration of edaravone to VPA group. Ahmad et al. [45] revealed that treatment with edaravone to cerebral ischemic rats resulted in the elevation of G6PD activity. The increase in its activity may probably be attributed to overexpression of G6PD, which was associated with a decrease in intracellular ROS accumulation [46]. MPO, a cationic heme-containing peroxidase, is found mainly in activated neutrophils and to a lesser degree in lysosomes of monocytes. Increased MPO activity serves as a local marker of tissue injury [47]. In the present study, MPO activity, a marker of local mediator of tissue damage, significantly increased in VPA treated group. Our finding is consistent with an earlier published report on VPA toxicity on different tissues [48]. Elevation of MPO activity in testicular tissue may be associated with activation of neutrophils, triggered by excessive generation of ROS. The decrease in the activity of MPO in the testis was detected when edaravone was administered to the VPA group. These outcomes were in parallel with the results of Tunali-Akbay et al. [35]. $\mathrm{Na}^{+} / \mathrm{K}^{+}$-ATPase, also known as $\mathrm{Na}^{+} / \mathrm{K}^{+}$-pump, is an amphipathic heterodimeric protein composed of a and $\beta$ subunits that is found in several membrane segments. The a subunit is located in the testicles and in the middle region of the sperm [49]. In this study, we observed a remarkable decrease in $\mathrm{Na}^{+} / \mathrm{K}^{+}$-ATPase activity in VPA treated rats as compared to control group. On the other hand, edaravone treatment resulted in the restoration of these enzymes activity. Similar results were reported by Hacihasanoglu Cakmak and Yanardag [3] and Gezginci-Oktayoglu et al. [4], respectively. SDH reversibly catalyzes the oxidation reaction of sorbitol to fructose with the cofactor NAD. Moreover, this enzyme is found in the cytoplasm and mitochondria of liver and kidney, as well as seminal vesicles that are also responsible for supplying energy [39]. In the current study, there was detected an obvious increase in SDH activity in VPA group. In a study examining VPA-toxicity on rat's liver, hepatic SDH activity elevated as a result of administration of VPA to rats [50]. SDH activity notably declined when the rats were treated with edaravone. Similar findings were reported by Hacihasanoglu Cakmak and Yanardag [3]. A decrease in SDH activity may have caused an improvement in testicular tissue following edaravone administration.

The determination of AOPP, as well as PC levels, are the most practical biomarker of oxidative protein damage. Tissues damaged by oxidative stress usually contain increased concentrations of carbonylated proteins [51]. In this study, both AOPP and PC levels notably elevated in VPA given group. In a study examining the toxic effects of VPA on testicular tissue and epididymides of Wistar rats, PC levels were shown to remarkably increase in the experimental group [5]. This outcome was in harmony with our findings. Edaravone treatment to VPA group reversed these effects through showing excellent antioxidant effect against VPA-induced oxidative damage, thereby decreasing oxidation and carbonylation of proteins. This effect may be due to detoxifying free radicals and/or inhibiting protein carbonylation by direct carbonyl-scavenging effect [16,52]. NO is both water and lipid-soluble molecule that is involved in physiological and pathophysiological conditions such as tissue injury. VPA treatment caused a notable increase in NO levels as compared to control rats. A possible cause of an increase in NO levels may be due to oxidative stress, triggering the elevation of nitrate and nitrite levels which are source of endogenous NO production in the testis [53]. In a study conducted on the protective effects of L-cysteine treatment against oxidative damage caused by SVP in the testis of rats, it was found that NO levels notably increased in testicular tissue [7]. In the present study, edaravone treatment of VPA group gave rise to a notable decline in NO levels. Edaravone has been effective in supporting antioxidant mechanisms by acting as a direct free radical scavenger. On the other hand, DNA 
content in VPA group was significantly elevated when compared with control rats. The increase in DNA content may be caused by rather elevated LPO, ROS, and TOS levels, which are an indicator of oxidative stress. Furthermore, ROS and TOS levels may indicate that testicular oxidative stress may be involved in the elevation of DNA damage [54].

\section{CONCLUSION}

Considering the present outcomes, it can be suggested that VPA treatment may give rise to oxidative stress. This is indicated by the elevation of LPO, AOPP, PC, and NO levels, and consequently the overproduction of ROS. As obviously seen, testicular damage may be due to an increase in enzymatic antioxidants such as glutathione-related enzymes as well as testicular oxidative stress biomarkers (that included ACP, ALP, and LDH). On the other hand, administration of edaravone, a robust antioxidant agent, attenuates lipid peroxidation and protein oxidation. Moreover, edaravone improves testicular biomarkers against VPA-induced oxidative stress. These results suggest that edaravone showed a beneficial effect on testicular injury caused by VPA-induced excessive formation of free radicals.

\section{MATERIALS AND METHODS}

\subsection{Chemicals and apparatus}

All chemicals were of the highest purity. Unless otherwise stated, all chemicals were supplied from Merck Chemical Company (Darmstdat, Germany) and/or Sigma-Aldrich Chemical Company (St. Louis, MO, USA). The VPA and edaravone were purchased from Merck (Darmstadt, Germany) with catalog numbers 8.14439 and 8.07080, respectively.

\subsection{Animals and experimental design}

Male Sprague Dawley rats, 2.5-3 months old and clinically healthy, were chosen in this study. The rats were randomly separated into four groups as follows: Group I $(n=8)$ which comprised intact control animals. Group II $(n=10)$ were intraperitoneally (i.p.) given only edaravone $(30 \mathrm{mg} / \mathrm{kg} /$ day $)$ for seven days [55]. Group III $(\mathrm{n}=10)$ were given only VPA i.p. $(500 \mathrm{mg} / \mathrm{kg} /$ day) for seven days [3], and lastly, Group IV ( $\mathrm{n}=10)$ which were given VPA+ edaravone i.p. (at the same dose and at the same time). After overnight fasting, all animals were sacrificed under anesthesia (on the 8th day).

All the experimental procedures were approved by the Istanbul University Local Ethics Committee on Animal Research (2010/54-the ethic committee number). The rats were maintained under standard environmental conditions and fed with laboratory pellet chow and given water.

\subsection{Biochemical analyses}

Testicular tissue samples were dissected out, immediately washed in ice-cold $0.9 \% \mathrm{NaCl}$ solution, and then homogenized to make up to $10 \%$ homogenate $(\mathrm{w} / \mathrm{v})$. These homogenates were centrifuged at $10000 \times \mathrm{g}$ at $4^{\circ} \mathrm{C}$ for 10 minutes. After centrifugation, only clear supernatants were collected. The clear supernatants were used for biochemical assays. For this purpose, GSH and LPO levels were determined according to the methods published previously by Beutler [56] and Ledwozyw et al. [57], respectively. ROS were assessed according to Zhang et al. [25]. TOS, TAS, and OSI levels were estimated by the methods described by Erel [26,27], respectively. Oxidative stress index (OSI) was calculated by the formula OSI (arbitrary unit) $=[(\mathrm{TOS}, \mu \mathrm{mol} / \mathrm{g}$ protein)/(TAS, $\mu \mathrm{mol} / \mathrm{g}$ protein)x100]. CAT, SOD, GPx, GR, and GST activities were done according to the methods published previously by Aebi [58], Mylroie et al. [59], Paglia and Valentine [60] and modified by Wendel [61], Beutler [62], and Habig and Jakoby [63], respectively. ACP, ALP, and LDH activities were assessed according to Walter and Schütt [64] and Bais and Philcox [65], respectively. GGT, $\mathrm{Na}^{+} / \mathrm{K}^{+}$-ATPase, MPO, G6PD, and SDH activities were evaluated by the methods described by Szasz [66], Ridderstap and Bonting [67], Wei and Frenkel [68], Beutler [69], and Barretto and Beutler [70], respectively. AOPP, PC, and NO levels and DNA contents were determined according to the methods of Witko-Sarsat et al. [71], Levine et al. [51], Miranda et al. [72] and Burton [73], respectively. The protein content in the supernatants was estimated by the method of Lowry using Bovine Serum Albumin (BSA) as standard [74].

\subsection{Statistical analyses}

The results of the current study were evaluated by using GraphPad Prism Software, version 6.01 (San Diego, USA). Data were stated as mean \pm standard deviation (S.D.) by using one-way analysis of variance 
(One-way ANOVA) followed by Tukey's multiple comparison post hoc test. $\mathrm{P}<0.05$ was considered statistically significant.

Acknowledgements: This work was supported by Istanbul University-Cerrahpasa Scientific Research Projects Unit [Grant number 31214].

Author contributions: Concept - B.B.B., N.H.C., R.Y.; Design - B.B.B., N.H.C., R.Y.; Supervision - R.Y.; Resources C.C.., B.B.B., N.H.C., R.Y.; Materials - C.C., B.B.B., N.H.C., R.Y.; Data Collection and/or Processing - C.C., B.B.B.; Analysis and/or Interpretation - C.C., B.B.B.; Literature Search - C.C., B.B.B., N.H.C., R.Y.; Writing - C.C.; B.B.B., R.Y.; Critical Reviews - C.C., B.B.B., N.H.C., R.Y.

Conflict of interest statement: The authors declared no conflict of interest.

Ethics committee approval: All the experimental procedures were approved by the Istanbul University Local Ethics Committee on Animal Research (2010/54-the ethic committee number).

\section{REFERENCES}

[1] Wu MY, Chang FY, Ke JY, Chen CS, Lin PC, Wang TS. Valproic acid-induced hyperammonemic encephalopathy in a patient with bipolar disorder: a case report. Brain Sci. 2020; 10: 187. [CrossRef]

[2] Rithanya P, Ezhilarasan D. Sodium valproate, a histone deacetylase inhibitor, provokes reactive oxygen speciesmediated cytotoxicity in human hepatocellular carcinoma cells. J Gastrointest Cancer, 2021; 52: 138-144. [CrossRef]

[3] Hacihasanoglu Cakmak N, Yanardag R. Edaravone, a free radical scavenger, protects liver against valproic acid induced toxicity. J Serb Chem Soc. 2015; 80: 627-637. [CrossRef]

[4] Gezginci-Oktayoglu S, Turkyilmaz IB, Ercin M, Yanardag R, Bolkent S. Vitamin U has a protective effect on valproic acid-induced renal damage due to its anti-oxidant, anti-inflammatory, and anti-fibrotic properties. Protoplasma, 2016; 253: 127-135. [CrossRef]

[5] Maneenin C, Burawat J, Maneenin N, Nualkaew S, Arun S, Sampannang A, Iamsaard S. Antioxidant capacity of Momordica charantia extract and its protective effect on testicular damage in valproic acid-induced rats. Int J Morphol. 2018; 36: 447-453.

[6] Isojärvi JIT, Taubøll E, Herzog AG. Effect of antiepileptic drugs on reproductive endocrine function in individuals with epilepsy. CNS Drugs, 2005; 19: 207-223. [CrossRef]

[7] Al-Salmi FA, Al-Eisa R, Hamza RZ, Khaled HE, El-Shenawy NS. Protective effect of 1-cysteine against sodium valproate-induced oxidant injury in testis of rats. Int J Pharmacol. 2019; 15: 248-256. [CrossRef]

[8] Arun S, Chaiyamoon A, Lapyuneyong N, Bunsueb S, Wu ATH, Iamsaard S. Chronic stress affects tyrosine phosphorylated protein expression and secretion of male rat epididymis. Andrologia, 2021; 53(3): e13981. [CrossRef]

[9] Iamsaard S, Tongpan S, Yannasithinon S, Arun S, Wu ATH, Sukhorum W. Effect of chronic stress on expression and secretion of seminal vesicle proteins in adult rats. Andrologia, 2021; 53(1): e13800. [CrossRef]

[10] Ourique GM, Pês TS, Saccol EMH, Finamor IA, Glanzner WG, Baldisserotto B, Pavanato MA, Gonçalves PBD, Barreto KP. Resveratrol prevents oxidative damage and loss of sperm motility induced by long-term treatment with valproic acid in Wistar rats. Exp Toxicol Pathol. 2016; 68: 435-443. [CrossRef]

[11] Zhao S, Wang X, Wang Y, Xu J, Zhu G, Zhao C, Teng W. Effects of valproate on reproductive endocrine function in male patients with epilepsy: a systematic review and meta-analysis. Epilepsy Behav. 2018; 85: 120-128. [CrossRef]

[12] Gülçin, I. Antioxidant activity of food constituents: an overview. Arch Toxicol. 2012; 86(3): 345-391. [CrossRef]

[13] Gulcin, I. Antioxidants and antioxidant methods: an updated overview. Arch Toxicol. 2020; 94, 651-715. [CrossRef]

[14] Nicco C, Batteux F. ROS modulator molecules with therapeutic potential in cancers treatments. Molecules, 2018; 23: 84. [CrossRef]

[15] Poljsak B, Šuput D, Milisav I. Achieving the balance between ROS and antioxidants: when to use the synthetic antioxidants. Oxid Med Cell Longev. 2013; 2013: 956792. [CrossRef]

[16] Kikuchi K, Tancharoen S, Takeshige N, Yoshitomi M, Morioka M,Tanaka E. The efficacy of edaravone (radicut), a free radical scavenger, for cardiovascular disease. Int J Mol Sci. 2013; 14: 13909-13930. [CrossRef] 
[17] Tsounapi P, Saito M, Dimitriadis F, Koukos S, Shimizu S, Satoh K, Takenaka A, Sofikitis N. Antioxidant treatment with edaravone or taurine ameliorates diabetes-induced testicular dysfunction in the rat. Mol Cell Biochem. 2012; 369: 195-204. [CrossRef]

[18] Chateauvieux S, Morceau F, Dicato M, Diederich M. Molecular and therapeutic potential and toxicity of valproic acid. BioMed Res Int. 2010; 2010: 479364. [CrossRef]

[19] Abdelkader NF, Elyamany M, Gad AM, Assaf N, Fawzy HM, Elesawy WH. Ellagic acid attenuates liver toxicity induced by valproic acid in rats. J Pharmacol Sci. 2020; 143: 23-29. [CrossRef]

[20] Tong V, Teng XW, Chang TKH, Abbott FS. Valproic acid II: effects on oxidative stress, mitochondrial membrane potential, and cytotoxicity in glutathione-depleted rat hepatocytes. Toxicol Sci. 2005; 86: 436-443. [CrossRef]

[21] Watanabe K, Morinaka Y, Iseki K, Watanabe T, Yuki S, Nishi H. Structure-activity relationship of 3-methyl-1-phenyl2-pyrazolin-5-one (edaravone). Redox Rep. 2003; 8: 151-155. [CrossRef]

[22] Vidya M, Subramanian S. Effects of a-ketoglutarate on antioxidants and lipid peroxidation products in rats treated with sodium valproate. J Appl Biomed. 2006; 4: 141-146.

[23] Hamza AA, Amin AMR. Apium graveolens modulates sodium valproate-induced reproductive toxicity in rats. J Exp Zool A Ecol Genet Physiol. 2007; 307(4): 199-206. [CrossRef]

[24] Ourique GM, Saccol EMH, Pês TS, Glanzner WG, Schiefelbein SH, Woehl VM, Baldisserotto B, Pavanato MA, Gonçalves PBD, Barreto KP. Protective effect of vitamin E on sperm motility and oxidative stress in valproic acid treated rats. Food Chem Toxicol. 2016; 95: 159-167. [CrossRef]

[25] Zhang Y, Chen J, Ji H, Xiao ZG, Shen P, Xu LH. Protective effects of Danshen injection against erectile dysfunction via suppression of endoplasmic reticulum stress activation in a streptozotocin-induced diabetic rat model. BMC Complement Altern Med. 2018; 18: 343. [CrossRef]

[26] Erel O. A novel automated direct measurement method for total antioxidant capacity using a new generation, more stable ABTS radical cation. Clin Biochem. 2004; 37: 277-285. [CrossRef]

[27] Erel O. A new automated colorimetric method for measuring total oxidant status. Clin Biochem. 2005; 38: 1103-1111. [CrossRef]

[28] Savran M, Asc1 H, Armagan I, Erzurumlu Y, Azırak S, Ozer MK, Bilgic S, Tastemir Korkmaz D. Thymoquinone could be protective against valproic acid- induced testicular toxicity by antioxidant and anti- inflammatory mechanisms. Andrologia. 2020; 52(7): e13623. [CrossRef]

[29] Schulpis KH, Lazaropoulou C, Regoutas S, Karikas GA, Margeli A, Tsakiris S, Papassotiriou I. Valproic acid monotherapy induces DNA oxidative damage. Toxicology. 2006; 217: 228-232. [CrossRef]

[30] Bayrak BB, Yilmaz S, Hacihasanoglu Cakmak N, Yanardag R. The effects of edaravone, a free-radical scavenger in lung injury induced by valproic acid demonstrated via different biochemical parameters. J Biochem Mol Toxicol. 2021; 35(9): e22847. [CrossRef]

[31] Arslan EA, Arslan E, Yaman SÖ, Karahan SC. The effects of edaravone on experimental brain ischemia/reperfusion injury in rats. Haydarpasa Numune Med J. 2019; 59: 197-202. [CrossRef]

[32] Mandil R, Rahal A, Prakash A, Garg SK, Gangwar NK, Swain DK. Ameliorative potential of a-tocopherol against flubendiamide and copper-induced testicular-insult in Wistar rats. Chem Biol Interact. 2016; 260: 91-101. [CrossRef]

[33] Çeribaşı AO, Sakin F, Türk G, Sönmez M, Ateşşahin A. Impact of ellagic acid on adriamycin-induced testicular histopathological lesions, apoptosis, lipid peroxidation and sperm damages. Exp Toxicol Pathol. 2012; 64: 717-724. [CrossRef]

[34] Saini AK, Kumar AHS, Sharma SS. Preventive and curative effect of edaravone on nerve functions and oxidative stress in experimental diabetic neuropathy. Eur J Pharmacol. 2007; 568: 164-172. [CrossRef]

[35] Tunali-Akbay T, Alev B, Tunali S, Oktay S, Emekli-Alturfan E, Ipekci H, Koc Ozturk L, Yanardag R, Yarat A. Protective role of edaravone against valproic acid induced changes in skin. Indian J Exp Biol. 2017; 55: $286-291$.

[36] Peruquetti RL, Taboga SR, Azeredo-Oliveira MTV. Expression of acid phosphatase in the seminiferous epithelium of vertebrates. Genet Mol Res. 2010; 9: 620-628. [CrossRef]

[37] Long M, Yang S, Dong S, Chen X, Zhang Y, He J. Characterization of semen quality, testicular marker enzyme activities and gene expression changes in the blood testis barrier of Kunming mice following acute exposure to zearalenone. Environ Sci Pollut Res. 2017; 24: 27235-27243. [CrossRef] 
[38] Rizk SM, Zaki HF, Mina MA. Propolis attenuates doxorubicin-induced testicular toxicity in rats. Food Chem Toxicol. 2014; 67: 176-186. [CrossRef]

[39] Selvakumar E, Prahalathan C, Sudharsan PT, Varalakshmi P. Protective effect of lipoic acid on cyclophosphamideinduced testicular toxicity. Clin Chim Acta, 2006; 367: 114-119. [CrossRef]

[40] Li W, Wu Z, Zhang S, Cao R, Zhao J, Sun Z, Zou W. Augmented expression of gamma-glutamyl transferase 5 (GGT5) impairs testicular steroidogenesis by deregulating local oxidative stress. Cell Tissue Res. 2016; 366: 467-481. [CrossRef]

[41] Brodie MJ, Mintzer S, Pack AM, Gidal BE, Vecht CJ, Schmidt D. Enzyme induction with antiepileptic drugs: cause for concern? Epilepsia. 2013; 54: 11-27. [CrossRef]

[42] Hadzagic-Catibusic F, Hasanbegovic E, Melunovic M, Zubcevic S, Uzicanin S. Effects of carbamazepine and valproate on serum aspartate aminotransferase, alanine aminotransferase and gamma - glutamyltransferase in children. Med Arch. 2017; 71(4): 239-242. [CrossRef]

[43] Omidipour R, Zarei L, Boroujeni MB, Rajabzadeh A. Protective effect of thyme honey against valproic acid hepatotoxicity in Wistar rats. BioMed Res Int. 2021; 2021: 8839898. [CrossRef]

[44] Stanton RC. Glucose-6-phosphate dehydrogenase, NADPH, and cell survival. IUBMB Life, 2012; 64: $362-369$. [CrossRef]

[45] Ahmad A, Khan MM, Javed H, Razai SS, Ishrat T, Khan MB, Safhi MM, Islam F. Edaravone ameliorates oxidative stress associated cholinergic dysfunction and limits apoptotic response following focal cerebral ischemia in rat. Mol Cell Biochem. 2012; 367: 215-225. [CrossRef]

[46] Leopold JA, Zhang YY, Scribner AW, Stanton RC, Loscalzo J. Glucose-6-phosphate dehydrogenase overexpression decreases endothelial cell oxidant stress and increases bioavailable nitric oxide. Arterioscler Thromb Vasc Biol. 2003; 23: 411-417. [CrossRef]

[47] Aratani Y. Myeloperoxidase: its role for host defense, inflammation, and neutrophil function. Arch Biochem Biophys. 2018; 640: 47-52. [CrossRef]

[48] Kassab AA, Aboregelab AM, Shalaby AM. Edaravone attenuates lung injury in a hind limb ischemia-reperfusion rat model: a histological, immunohistochemical and biochemical study. Ann Anat. 2020; 228: 151433. [CrossRef]

[49] Clausen MV, Hilbers F, Poulsen $\mathrm{H}$. The structure and function of the Na, K-ATPase isoforms in health and disease. Front Physiol. 2017; 8: 371. [CrossRef]

[50] Sokmen BB, Tunali S, Yanardag R. Effects of vitamin U (S-methyl methionine sulphonium chloride) on valproic acid induced liver injury in rats. Food Chem Toxicol. 2012; 50: 3562-3566. [CrossRef]

[51] Levine RL, Garland D, Oliver CN, Amici A, Climent I, Lenz AG, Ahn BW, Shaltiel S, Stadtman ER. Determination of carbonyl content in oxidatively modified proteins. Methods Enzymol. 1990; $186: 464-478$. [CrossRef]

[52] Aldini G, Vistoli G, Regazzoni L, Benfatto MC, Bettinelli I, Carini M. Edaravone inhibits protein carbonylation by a direct carbonyl-scavenging mechanism: focus on reactivity, selectivity, and reaction mechanisms. Antioxid Redox Signal. 2010; 12(3): 381-392. [CrossRef]

[53] Koltuksuz U, Irmak MK, Karaman A, Uz E, Var E, Ozyurt H, Akyol O. Testicular nitric oxide levels after unilateral testicular torsion/detorsion in rats pretreated caffeic acid phenethyl ester. Urol Res. 2008; 28: 360-363. [CrossRef]

[54] Smith R, Kaune H, Parodi D, Madariaga M, Rios R, Morales I, Castro A. Increased sperm DNA damage in patients with varicocele: relationship with seminal oxidative stress. Hum Reprod. 2006; 21: 986-993. [CrossRef]

[55] Tunali S. The effects of vitamin B6 on lens antioxidant system in valproic acid-administered rats. Hum Exp Toxicol. 2014; 33(6): 623-628. [CrossRef]

[56] Beutler E. Glutathione in Red Cell Metabolism: A Manual of Biochemical Methods, second ed., Grune and Stratton, New York, USA 1975.

[57] Ledwozyw A, Michalak J, Stepień A, Kadziołka A. The relationship plasma triglycerides, cholesterol, total lipids and lipid peroxidation products during human atherosclerosis. Clin Chim Acta. 1986; 155: 275-283. [CrossRef]

[58] Aebi H. Catalase in vitro. Methods Enzymol. 1984; 105: 121-126. [CrossRef]

[59] Mylroie AA, Collins H, Umbles C, Kyle J. Erythrocyte superoxide dismutase activity and other parameters of copper status in rats ingesting lead acetate. Toxicol Appl Pharmacol. 1986; 82: 512-520. [CrossRef]

[60] Paglia DE, Valentine WN. Studies on the quantitative and qualitative characterization of erythrocyte glutathione peroxidase. J Lab Clin Med. 1967; 70: 158-169. 
[61] Wendel A. Glutathione peroxidase. Methods Enzymol. 1981; 77: 325-333. [CrossRef]

[62] Beutler E. Glutathione in Red Cell Metabolism: A Manual of Biochemical Methods, Vol.12, Grune and Stratton, London, UK 1971.

[63] Habig WH, Jakoby WY. Assays for differentiation of glutathione-S-transferases. Methods Enzymol. 1981; 77: $398-405$. [CrossRef]

[64] Walter K and Schütt C. Acid and alkaline phosphatase in serum (twopoint method). In: Bergmeyer HU. (Ed.) Methods of Enzymatic Analysis. Verlag, Chemie GmbH, Florida (FL): Boca Raton, 1974, Vol 2, pp.856-860.

[65] Bais R, Philcox M. Approved recommendation on IFCC methods for the measurement of catalytic concentration of enzymes. Part 8. IFCC method for lactate dehydrogenase (1-Lactate: NAD+Oxidoreductase, EC 1.1.1.27). International Federation of Clinical Chemistry (IFCC). Eur J Clin Chem Clin Biochem. 1994; 32: 639-655.

[66] Szasz G. A kinetic photometric method for serum y-glutamyl transpeptidase, Clin Chem. 1969; 15: 124-136. [CrossRef]

[67] Ridderstap AS, Bonting SL. $\mathrm{Na}^{+}-\mathrm{K}^{+}$-activated ATPase and exocrine pancreatic secretion in vitro. Am J Physiol. 1969; 217: 1721-1727. [CrossRef]

[68] Wei H, Frenkel K. In vivo formation of oxidized DNA bases in tumor promoter-treated mouse skin. Cancer Res. 1991; 51: 4443-4449.

[69] Beutler E. Glutathione in Red Cell Metabolism: A Manual of Biochemical Methods, third ed., Grune and Stratton, New York, USA 1984.

[70] Barretto OCO, Beutler E. The sorbitol-oxidizing enzyme of red blood cells. J Lab Clin Med. 1975; 85: 645-649.

[71] Witko-Sarsat V, Friedlander M, Capeillère-Blandin C, Nguyen-Khoa T, Nguyen AT, Zingraff J, Jungers P, Béatrice Descamps B. Advanced oxidation protein products as a novel marker of oxidative stress in uremia. Kidney Int. 1996; 49: 1304-1313. [CrossRef]

[72] Miranda KM, Espey MG, Wink DA. A rapid, simple spectrophotometric method for simultaneous detection of nitrate and nitrite. Nitric Oxide, 2001; 5: 62-71. [CrossRef]

[73] Burton K. A study of the conditions and mechanism of the diphenylamine reaction for the colorimetric estimation of deoxyribonucleic acid. Biochem J. 1956; 62: 315-323. [CrossRef]

[74] Lowry OH, Rosebrough NJ, Farr AL, Randall RJ. Protein measurement with the Folin phenol reagent. J Biol Chem. 1951; 193: 265-275. [CrossRef]

This is an open access article which is publicly available on our journal's website under Institutional Repository at http://dspace.marmara.edu.tr. 